\title{
Periocular basal cell carcinoma: cost of topical immunotherapy versus estimated cost of surgical treatment
}

\author{
Carcinoma basocelular periocular: custo da imunoterapia \\ tópica versus custo estimado do tratamento cirúrgico
}

Erick Marcet Santiago de Macedo ${ }^{1}$, Rachel Camargo Carneiro ${ }^{1}$, Pedro Carlos Carricondo², Suzana Matayoshi ${ }^{3}$

\begin{abstract}
Purpose: The objective of this study was to compare the estimated cost of clinical and surgical treatment for basl cell carcinoma of the eyelid. Methods: This was a pilot study of 12 patients with basal cell carcinoma receiving treatment with 5\% imiquimod cream at the ocular plastic surgery center, medical school University of São Paulo (HC-FMUSP, Brazil). The cost of clinical treatment was estimated based on the time of treatment and amount of medication consumed by patients in the home setting. The cost of surgical treatment was estimated by ophthalmologists with experience in reconstructive plastic surgery based on analysis of images of the same patients. Surgeons responded to a questionnaire with four questions about surgical technique, surgical materials required, estimated duration of surgery and type of anesthesia.Results: Immunotherapy lasted from 8 to 12 weeks. All patients reported each coldstored sachet with $5 \%$ imiquimod cream lasted 3 days. According to the institution, a box with 12 sachets costs BRL 480.00. Patients required 1.58-3.11 boxes for complete treatment, corresponding to a total cost of BRL 758.401,492.80. Based on image analysis, surgeons evaluated surgery would require 1-3 hours. The estimated cost of surgery room and staff was BRL 263.00, to which the cost of supplies was added. Thus, the total cost of surgical treatment was BRL 272.61-864.82. On the average, immunotherapy was 57,64\% more costly than surgical treatment. Conclusions: Malignant eyelid tumors are a common finding in clinical ophthalmology. Surgery is still the treatment of choice at our institution, but immunotherapy with $5 \%$ imiquimod cream may be indicated for patients with multiple lesions or high surgical risk and for patients declining surgery for reasons of fear or esthetic concerns. The ability to estimate costs related to the treatment of malignant eyelid tumors is an important aid in the financial planning of health care institutions. Further studies should evaluate the possibility of institutions equating the cost of immunotherapy and surgical treatment by acquiring similar but less expensive medications.
\end{abstract}

Keywords: Carcinoma, basal cell carcinoma/surgery; Carcinoma, basal cell /economy; Carcinoma, basal cell carcinoma/drug therapy; Eyelid neoplasms; Antineoplastic agents/therapeutic use; Biopsy; Health care costs

\footnotetext{
'Department of Ophthalmology, Hospital das Clínicas, Medical School, Universidade de São Paulo (USP) - São Paulo (SP), Brazil; ${ }^{2}$ Department of Ophthalmology, Hospital das Clínicas, Medical School, Universidade de São Paulo (USP) - São Paulo (SP), Brazil; ${ }^{3}$ Department of Ophthalmology, Hospital das Clínicas, Medical School, Universidade de São Paulo (USP) - São Paulo (SP), Brazil;

Study conducted at the Ocular Plastic Surgery Center, Department of Ophthalmology, Hospital das Clínicas, Medical School, Universidade de São Paulo (USP) - São Paulo (SP), Brazil.
}

Clinical Trials.gov Identifier: NCT00803907

Apoio do CNPq - processo n 480144/2008-7

Os autores declaram inexistir conflitos de interesse

Recebido para publicação em 2/11/2011 - Aceito para publicação em 2/3/2011 


\section{ResUmo}

Objetivo: O objetivo deste estudo foi comparar os custos do tratamento clínico e cirúrgico para carcinoma basocelular palpebral. Método: Neste estudo piloto, doze pacientes com carcinoma basocelular atendidos no departamento de Plástica Ocular do Hospital das Clínicas da Universidade de São Paulo (HC-FMUSP) foram tratados com imiquimode creme $5 \%$. O Custo do tratamento clínico foi estimado baseado no tempo de tratamento e quantidade de medicação utilizada pelo paciente no domicilio. O custo do tratamento cirúrgico foi baseado na análise das imagens dos mesmos pacientes submetidos ao tratamento clínico, por Oftalmologistas experientes em cirurgia plástica reconstrutiva. Os profissionais responderam um questionário com quatro perguntas relacionadas à técnica cirúrgica, à quantidade de material gasto, ao tempo cirúrgico estimado e anestesia utilizada. Resultados: O tempo de tratamento clínico variou entre 8 a 12 semanas. Todos os pacientes referem que um sachê dura 3 dias e armazenaram na geladeira. O valor informado pela instituição na compra do imiquimode creme $5 \%$ foi de 40,00 reais/sachê, portanto o custo da caixa medicação foi de $\mathrm{R} \$ 480,00$ a caixa. A média de caixas consumidas por tratamento variou de 1,58 a 3,11 caixas, portanto o custo do tratamento clínico variou de $\mathrm{R} \$ 758,40$ a $\mathrm{R} \$ 1.492,80$. Os cirurgiões avaliaram as imagens dos pacientes submetidos ao tratamento clínico e informaram que o tempo estimado de cirurgia para cada paciente seria de 1 a 3 horas se a opção fosse cirúrgica. Foi estimado um custo de centro cirúrgico, incluindo espaço físico e pessoal de $\mathrm{R} \$ 263,00$ ao qual foi acrescido o valor do material que seria utilizado. Assim, observou-se que o valor variou entre $\mathrm{R} \$ 272,61$ a $\mathrm{R} \$ 864,82$ para o tratamento cirúrgico. O tratamento clínico em média foi de 57,64\% superior ao tratamento cirúrgico. Conclusão: As lesões palpebrais malignas são responsáveis por uma porção importante na prática clínica oftalmológica. A cirurgia continua sendo o padrão ouro em nossa instituição, porém casos em que a cirurgia não é uma opção, como pacientes com alto risco cirúrgico, aqueles com múltiplas lesões ou que se negam a cirurgia, seja por fobia ou motivo estético, podemos lançar mão de terapias alternativas como a imunoterapia com o imiquimode creme $5 \%$. Conhecer a estimativa dos custos relacionados ao tratamento dessa patologia é fundamental para o planejamento financeiro das instituições. A instituição com a possibilidade de aquisição de uma mesma medicação com valor mais acessível permitiria equilibrar o custo do tratamento clínico com o cirúrgico e deverão ser avaliados em trabalhos futuros

Descritores: Carcinoma basocelular/cirurgia; Carcinoma basocelular/economia Carcinoma basocelular/ quimioterapia; Neoplasias palpebrais; Antineoplásicos/uso terapêutico; Biópsia; Custos de cuidados de saúde

\section{INTRODUCTION}

B asal cell carcinoma (BCC) is the most common type of periocular neoplasm, with an annual incidence of $10 \%{ }^{(1)}$ In the periocular area, BCC currently represents $20 \%$ of all tumors and $90 \%$ of neoplasms. ${ }^{2}$ The increasing incidence makes it urgent to evaluate treatment costs and financial impacts on public health system.

Considered reliable and effective, surgical excision with safety margins, followed by primary reconstruction of the affected area, is the standard treatment for periocular BCC. ${ }^{(3)}$ However, the periocular region is difficult to manage, requiring special surgical techniques to avoid damage to eyelid function. In addition, surgical treatment often involves the removal of a large amount of tissue in detriment of the patient's appearance. ${ }^{(4)}$ Several alternative therapies have been proposed to help patients with contraindication for conventional treatment. One of these, immunotherapy with $5 \%$ imiquimod cream, has been widely tested and found to be efficacious in the treatment of BCC. ${ }^{(5-7)} \mathrm{It}$ is supposed to be costly, but an economic evaluation, with a cost-outcome analysis, is necessary to estimate the actual contribution of this procedure in skin cancer treatment, in comparison with the reference procedure, ie traditional surgical excIt is supposed to be costly, but an economic evaluation, with a cost-outcome analysis, is necessary to estimate the actual contribution of this procedure in skin cancer treatment, in comparison with the reference procedure, ie traditional surgical excision.

Few studies have compared the cost-effectiveness of surgical and clinical treatment for superficial BCC. Exceptions include a study on patients with $\mathrm{BCC}$ in the lower limbs ${ }^{8}$ and a study comparing dermatological and non-dermatological services. ${ }^{(9)}$ However, no previous study compared the cost of clinical and surgical treatment of $\mathrm{BCC}$ in the periocular area.

\section{Methods}

This pilot study, conducted at the Ocular Plastic Surgery Center (HC-FMUSP,Brazil), involved 12 patients with periocular lesions meeting the inclusion criteria for treatment with $5 \%$ imiquimod cream. All lesions were nodular BCC confirmed by 2-mm punch biopsy. 
Table 1

Cost of clinical treatment versus estimated cost of surgical treatment for periocular basal cell carcinoma

\begin{tabular}{ccccc}
\hline Patient & $\begin{array}{c}\text { Size of } \\
\text { lesion(mm) }\end{array}$ & $\begin{array}{c}\text { Boxes (12 sachets) } \\
\text { of 5\% imiquimod } \\
\text { cream consumed }\end{array}$ & $\begin{array}{c}\text { Cost of clinical } \\
\text { treatment in BRL* }\end{array}$ & $\begin{array}{c}\text { Estimated cost } \\
\text { of surgical } \\
\text { treatment in BRL }\end{array}$ \\
\hline 1 & $11 \times 8$ & 1.58 & 758.40 & 594.54 \\
2 & $11 \times 10$ & 2.33 & $1,118.40$ & 864.80 \\
3 & $11 \times 9$ & 2.33 & $1,118.40$ & 601.04 \\
4 & $19 \times 11$ & 2.52 & $1,209.60$ & 601.04 \\
5 & $12.5 \times 5$ & 3.11 & $1,492.80$ & 502.77 \\
6 & $27 \times 10$ & 2.33 & $1,118.40$ & 543.81 \\
7 & $5 \times 5$ & 1.58 & 758.40 & 272.61 \\
8 & $5 \times 5$ & 2.72 & $1,305.60$ & 272.61 \\
\hline
\end{tabular}

(*)According to the institution, in 2008/2009 the cost of a box with 12 sachets of $5 \%$ imiquimod cream was BRL 480.00

Table 2

Estimated cost in BRL of surgery room and staff at the Ocular Plastic Surgery Center (HC-FMUSP)

\begin{tabular}{lcccc}
\hline Breakdown & Month & Day & Hour & Minute \\
\hline Human resources & $34,337.25$ & $2,376.86$ & 237.69 & 3.96 \\
Facilities & $4,885.00$ & 244.25 & 24.43 & 0.41 \\
Depreciation of equipment & 200.00 & 16.67 & 1.67 & 0.03 \\
Total & $39,422.25$ & $2,637.78$ & 263.79 & 4.40 \\
\hline
\end{tabular}

Inclusion criteria

- Periocular basal cell carcinoma confirmed by biopsy;

- Clinical contraindication for surgical intervention;

- Refusal to submit to surgery for aesthetic or psychological reasons;

- Signing of informed consent form.

Exclusion criteria

- Previous treatment (in case of recurrence);

- Age under 12 years;

- Pregnancy or breastfeeding;

- Autoimmune disorder or previous inflammatory disease;

- Immunodepression.

The cost of clinical treatment was estimated based on the time of treatment and amount of medication used by patients in the home setting. The cost of surgical treatment was estimated by ophthalmologists with experience in reconstructive plastic surgery based on analysis of images of the same patients. Surgeons were given a questionnaire with four questions about surgical technique, surgical materials required, estimated duration of surgery and type of anesthesia.

\section{Results}

Immunotherapy lasted from 8 to 16 weeks 8 . Patients reported that each cold-stored sachet with 5\% imiquimod cream lasted 3 days. According to the institution, in 2008/2009 the cost of one sachet was BRL 40.00 (BRL 480.00 for a box with 12 sachets).

Patients required 1.58-3.11 boxes for complete treatment, corresponding to a total cost of BRL 758.401,492.80 (Table 1).

Based on image analysis, surgeons estimated surgery would require 1-3 hours. Based on earlier studies from the same institution, ${ }^{9,10}$ the cost of surgery room and staff was estimated to be BRL 263.00, to which the cost of supplies was added (Table 2).

Thus, the total cost of surgical treatment was BRL 272.61-864.82. On the average, immunotherapy was $57.64 \%$ more costly than surgical treatment. 


\section{Discussion}

Malignant eyelid tumors constitute an important part of clinical ophthalmology. At our institution, surgery is still the treatment of choice, except in patients with high surgical risk, multiple lesions or refusal to submit to surgery for aesthetic or psychological reasons. Such patients may opt for immunotherapy with $5 \%$ imiquimod cream. Knowledge of treatment costs is an essential subsidy to the financial planning of health care institutions.

Aguilar et al. evaluated the cost of treatment for superficial BCC in the lower limbs. Surgery was found to be more costly, but also more efficacious, than clinical treatment. ${ }^{(11)}$

Vanaclocha et al. evaluated the cost-effectiveness of treatment of superficial BCC using surgical excision or $5 \%$ imiquimod cream at dermatological and nondermatological services and found that clinical treatment reduced patient cost compared to surgery. ${ }^{(12)}$ In addition, the cost was higher at non-dermatological services due to more expensive surgical procedures and postoperative care.

Surgical treatment was less costly in our study than in the literature. However, the duration of surgery and need of supplies may have been underestimated by the fact that estimates were based on image analysis. Nevertheless, we believe that even if corrected for this difference, surgery would still be significantly less expensive than immunotherapy, especially in view of the low fixed labor costs of Brazilian public institutions.

The cost of clinical treatment was similar to what has been reported from other countries, but prolonged treatment would be financially unfeasible in the context of Brazilian public health care. The possibility of reducing clinical cost to the level of surgical cost through bulk purchase of less expensive but equivalent brands of medication might be explored in future studies.

\section{RefERENCES}

1. Wong CS, Strange RC, Lear JT. Basal cell carcinoma. BMJ. 2003;327(7418):794-8. Review.

2. Allali J, D'Hermies F, Renard G. Basal cell carcinomas of the eyelids. Ophthalmologica. 2005;219(2):57-71. Review.

3. Cook BE Jr, Bartley GB. Treatment options and future prospects for the management of eyelid malignancies: an evidence-based update. Ophthalmology. 2001;108(11):2088-98; quiz 2099-100, 2121.

4. Hamada S, Kersey T, Thaller VT. Eyelid basal cell carcinoma: non-Mohs excision, repair, and outcome. Br J Ophthalmol. 2005;89(8):992-4. Comment in $\mathrm{Br} \mathrm{J}$ Ophthalmol. 2006;90(5):660-1. Br J Ophthalmol. 2006;90(7):926; author reply $926-7$.
5. Gupta AK, Browne M, Bluhm R. Imiquimod: a review. J Cutan Med Surg. 2002;6(6):554-60.

6. Peris K, Campione E, Micantonio T, Marulli GC, Fargnoli MC, Chimenti S. Imiquimod treatment of superficial and nodular basal cell carcinoma: 12-week open-label trial. Dermatol Surg. 2005;31(3):318-23.

7. Schön MP, Schön M. Immune modulation and apoptosis in duction: two sides of the antitumoral activity of imiquimod. Apoptosis. 2004;9(3):291-8

8. Macedo EM , Carneiro RC, Matayoshi S. Imunoterapia tópica no tratamento do carcinoma basocelular periocular. Rev Bras Oftalmol. 2009;68(6):355-8.

9. Kara-Junior N, de Santhiago MR, Kawakami A, Carricondo P, Hida WT. Mini-rhexis for white intumescent cataracts. Clinics (Sao Paulo). 2009;64(4):309-12.

10. Kara-José Junior N, Avakian A, Lower LMT, Rocha AM, Cursino M, Alves MR. Facoemulsificação versus extração extracapsular manual do cristalino: análise de custos. Arq Bras Oftalmol. 2004;67(3):481-9.

11. Aguilar M, de Troya M, Martin L, Benítez N, González M. A cost analysis of photodynamic therapy with methyl aminolevulinate and imiquimod compared with conventional surgery for the treatment of superficial basal cell carcinoma and Bowen's disease of the lower extremities. J Eur Acad Dermatol Venereol. 2010;24(12):1431-6.

12. Vanaclocha F, Daudén E, Badía X, Guillén C, Conejo-Mir JS, Sainz de Los Terreros M, Hamel L, Llorens MA; HEIS Study Group. Cost-effectiveness of treatment of superficial basal cell carcinoma: surgical excision vs. imiquimod $5 \%$ cream. $\mathrm{Br}$ J Dermatol. 2007;156(4):769-71.

\section{Corresponding author:}

Erick Marcet Santiago de Macedo

Rua Dr. Veiga Filho, $n^{\circ} 207$, apto. 59, CEP 01229-001

- São Paulo, (SP), Brazil

e-mail: erickmarcet@yahoo.com.br 